УДК 343.98

DOI https://doi.org/10.32837/pyuv.v0i4.632

\author{
К. В. Гриненко \\ orcid.org/0000-0002-4077-3003 \\ ад’юнкт кафедри криліналістики та судової ледицини \\ Національної акаделії внутрішніх справ
}

\title{
ДОПУСТИМІСТЬ ДОКАЗІВ, ОТРИМАНИХ ПІД ЧАС ПРЕД'ЯВЛЕННЯ ОСОБИ ДЛЯ ВПІЗНАННЯ
}

У кримінальному судочинстві для допустимості доказів обов'язковим є дотримання передбачених кримінальним процесуальним законом способів і умов одержання доказів, тобто процесуальної форми. Фактичні дані про обставини кримінального правопорушення залишаються такими до моменту їх одержання процесуальним шляхом. Процесуальний порядок їх одержання за допомогою використання передбаченого законом джерела і відображення, фіксації в цьому джерелі перетворює їх на докази та є одним із важливих критеріїв допустимості. Процесуальна форма тісно пов' язана з формуванням джерела доказів, за її допомогою визначаються умови, порядок і послідовність провадження процесуальних дій, спрямованих на вилучення інформації з передбачених у законі носіїв [7, с. 146].

В аспекті тематики нашої наукової публікації необхідно відмітити, що питанню визначення поняття допустимості доказів вивчали такі науковці, як В.В. Золотих, В.І. Іщенко, Г.І. Кочаров, Г.М. Миньковський, Я.О. Мотовиловкер, Ю.К. Орлов, О.Р. Ратинов, Л.П. Самофалов, А.С. Сизоненко, О.М. Толочко, С.А. Шейфер та інші. Щодо пред'явлення для впізнання необхідно зазначити, що цій проблемі присвячували свої наукові роботи такі вчені, як Н.М. Ахтирська, Р.С. Бєлкін, М.П. Климчук, В.А. Колесник, В.О. Коновалова, В.Г. Лукашевич, Є.Д. Лук'янчиков, М.В. Салтевський, К.О. Чаплинський, Л.Д. Удалова, В.Ю. Шепітько та інші. Звичайно, що вказані наукові доробки мають велике значення для розкриття проблематики, але не вичерпають їі значення.

Мета статті - проаналізувати процесуальну форму як критерій допустимості доказів, зокрема під час проведення пред'явлення особи для впізнання. Досягнення мети потребує аналізу законодавства, наукових поглядів та практичних рішень з судової практики на предмет виявлення причин визнання доказів недопустимими укримінальному провадженні та окреслення шляхів їх вирішення.

Сьогодні поняття «процесуальна форма» не визначено жодним нормативним документом, а тому існують різні погляди науковців. Зокрема, на думку Я.О. Мотовиловкера, процесуальна форма - це форма, яку мають ті чи інші процесуальні дії, а також строки для провадження тієї чи іншої процесуальної дії [1, с. 84]. Л.П. Самофалов визначає процесуальну форму як порядок, умови, режим кримінально-процесуальної діяльності [8, с. 12]. 3.3. Зінатуллін вважає, що процесуальна форма обслуговує два тісно пов'язаних між собою завдання: по-перше, забезпечити достовірність доказів; по-друге, захистити права і законні інтереси громадян у кримінальному процесі [1, с. 108]. М.А. Чельцов вважає, що процесуальна форма - це порядок, умови та способи здійснення процесуальних дій [10, с. 47].

Проаналізувавши визначення поняття «процесуальна форма», можна зробити висновок, що це передбачений кримінальним процесуальним законом порядок діяльності сторони обвинувачення, сторони захисту, потерпілого і його представника, а також інших учасників кримінального провадження, спрямований на виконання завдань кримінального провадження з дотриманням засад кримінального провадження. Процесуальна форма є важливим критерієм допустимості доказів і забезпечує виконання основного завдання кримінального провадження - охорону прав, свобод та законних інтересів учасників кримінального провадження. На нашу думку, будь-яке порушення процесуальної форми є підставою для визнання доказів недопустимими, а тому є невіддільним критерієм допустимості доказів [7, с. 147].

На думку В.В. Золотих, критерієм допустимості доказів є правила про належну процедуру отримання доказу. Доказ має бути отриманий 3 дотриманням вимог закону відносно порядку проведення відповідної процесуальної дії, порядку фіксації її ходу та результатів. Тобто фактично йдеться про дотримання процесуальної форми. Далі автор висловлює думку про те, що процесуальна форма суворо формальна, порядок проведення кожної процесуальної дії детально регламентований в законі з метою гарантування прав учасників процесу. Відповідно, отримання доказів шляхом дій, не передбачених в законі, порушує права учасників процесу [2, с. 21].

Ми підтримуємо цю позицію, оскільки, як свідчить судова практика, недотримання процесуальної форми є підставою до визнання доказів недопустимими.

B.I. Іщенко до критеріїв допустимості доказів відносить дотримання вимог процесуальної форми під час формування відповідного виду доказів 
[3, с. 80-83]. Найбільш повно визнання поняття допустимості доказів дав О.М. Толочко. Він вважає, що допустимість - це властивість доказу, що характеризує його з погляду законності джерела фактичних даних (відомостей, інформації), а також способів одержання й форм закріплення фактичних даних, що містяться в такому джерелі, у порядку, передбаченому кримінальним процесуальним законом, тобто вповноваженою на це особою або органом у результаті проведення ними слідчої дії за умови суворого дотримання кримінально-процесуального закону, що визначає форми цієї слідчої дії [9, с. 189].

Сьогодні у ст. 86 КПК України надано загальне визначення поняття допустимості: допустимим визнається доказ за умови отримання його в порядку, встановленому КПК. Окрім цього, закон передбачає наслідки визнання доказу недопустимим. Так, у ч. 2 ст. 86 КПК України вказано, що недопустимий доказ не може бути використаний під час прийняття процесуальних рішень, на нього не може посилатися суд під час ухвалення судового рішення.

Аналіз постанови Пленуму Верховного Суду України «Про застосування Конституції України під час здійснення правосуддя» від 01.11.1996 p. № 9 свідчить, що суд зайняв більш виважену позицію під час визначення допустимості доказів. Як зазначено у постанові, докази повинні визнаватися одержаними незаконним шляхом, коли, наприклад, їх збирання та закріплення здійснено 3 порушенням встановленого кримінальним процесуальним законодавством порядку. Таким чином, не будь-яке порушення закону зумовлює визнання доказу недопустимим, а лише те, що безпосередньо пов'язане з встановленою законом формою збирання та фіксації відомостей та породжує сумніви в істинності змісту отриманих фактичних даних.

Суд, виносячи ухвалу про закінчення з'ясування обставин та перевірки їх доказами, має встановити належність, достатність, допустимість та визначити, які докази можуть бути основою для ухвалення рішення, а які слід визнати недопустимими.

$\mathrm{y}$ науковій літературі традиційно визначають певні критерії (умови) визнання доказів допустимими. Відповідно до позиції Касаційного кримінального суду у складі Верховного суду, висловленої в постанові від 11.02.2020 у справі № $761 / 33311 / 15$-к, під час розгляду кримінального провадження, даючи оцінку допустимості доказу, суд має проаналізувати критерії допустимості таких доказів, як-от: законність джерела, законність способу отримання, процесуальне оформлення перебігу й результатів слідчої дії. Критеріями допустимості доказів є:

- належне процесуальне джерело (ч. 2 ст. 84 КПК України містить вичерпний перелік проце- суальних джерел доказів, який розширеному тлумаченню не підлягає);

- належний суб'єкт збирання доказів (докази можуть бути зібрані тільки тими суб'єктами, які згідно з нормами КПК України мають на це право);

- належна процесуальна форма (встановлений КПК України порядок здійснення кримінального провадження загалом і проведення окремих процесуальних дій) [15].

Таким чином, процесуальна форма включає дотримання належної процедури одержання доказів та належну форму фіксації результатів дії. Загальновідомо, що основна частина доказів у кримінальному провадженні збирається шляхом проведення слідчих (розшукових) дій, зокрема під час проведення пред'явлення для впізнання.

Збирання доказів як елемент процесу доказування становить діяльність уповноважених на це осіб у порядку, передбаченому кримінальним процесуальним законодавством, щодо одержання відомостей про факти й обставини, що мають значення для кримінального провадження, і закріплення їх у формі, яка визначена законом. Щодо одержання доказів із належного джерела, у ч. 2 ст. 84 КПК України міститься вичерпний перелік процесуальних джерел доказів, до яких належать показання, речові докази, документи та висновки експертів. Цей перелік розширеному тлумаченню не підлягає, і будь-яка інформація, отримана не з процесуального джерела, не може буде використана як доказ.

Законодавець зобов'язує суб'єкта розслідування перед тим, як пред'явити об'єкт (особу, річ або труп) для впізнання, попередньо з'ясувати у особи, чи зможе вона впізнати об'єкт, пред'явлення якого планується, за яких обставин вона його спостерігала, за якими саме ознаками особа може впізнати об'єкт, про що складає протокол (ст. ст. 228-230 КПК України). Навіть якщо особа раніше вже була допитана щодо розслідуваної події й дала показання про ознаки об'єкта та обставини, за яких відбувалося його сприйняття, доцільно провести додатковий допит, предметом якого буде з'ясування сукупності ознак об'єкта і обставини його сприйняття, про які особа казала раніше, уточнення даних ознак та обстановки, за якою відбувалося сприйняття об'єкта. Саме результати такого допиту виступають для суб'єкта розслідування підставою для прийняття остаточного рішення щодо доцільності проведення пред'явлення для впізнання [5, с. 474].

Дотримання належної процедури одержання доказів є важливим елементом. Цей критерій допустимості доказів забезпечує послідовність проведення слідчих (розшукових) та інших процесуальних дій, належне оформлення рішення про проведення дії, дотримання умов і порядку здійснення таких дій. Належна процедура потребує до- 
тримання вимог законодавства щодо кола учасників, які повинні брати участь у провадженні певної дії або повинні бути повідомлені про проведення такої дії. Загальні правила проведення слідчих (розшукових) дій передбачені ст. 223 КПК України, а окремі вимоги до проведення пред'явлення особи для впізнання передбачені ст. 228 КПК України [11, с. 224].

Під час організації до проведення пред'явлення особи для впізнання забороняється попередньо показувати особі, яка впізнає, особу, яка повинна бути пред'явлена для впізнання. Тому слідчий чи прокурор зобов'язані вжити заходів, що виключають зустріч цих осіб і будь-які способи впливу на особу, яка здійснює впізнання. Така вимога закону пояснюється урахуванням властивостей людської психіки: людиною краще запам'ятовується і відтворюється той образ людини, що сприймався за часом, більш наближеним до часу проведення впізнання.

Отже, необхідно, щоб між сприйняттям особою, яка впізнає, та особою, яка пред'являється для впізнання, під час вчинення злочину чи за інших обставин, та моментом пред'явлення для пізнання не було опосередкованої ланки, тобто вони не повинні більше зустрічатися. Тим самим пояснюється заборона на проведення пред'явлення особи для впізнання після проведення пред'явлення впізнання за фотознімками, матеріалами відеозапису тої самої особи. Виключити вірогідність випадкової зустрічі особи, що впізнає, потрібно й 3 запрошеними особами (статистами), оскільки це буде підказкою для даної особи - кого впізнавати не треба, що також нівелює сутність цієї слідчої (розшукової) дії. Для цього рекомендується запрошувати особу, що впізнає, раніше того часу, на який заплановано провадження цієї дії, та забезпечити їі розміщення у такому місці, звідки він не зміг би побачити як прибувають інші ï̈ учасники [5, с. 390].

Цікавим є різновид процедури пред'явлення особи для впізнання в США - оперативне впізнання (англ. showup - показати, пред'явити). Таке впізнання зазвичай проводиться в тих ситуаціях, коли після вчинення кримінального правопорушення пройшов дуже короткий час. При цьому потерпілому або свідкові пред'являється тільки один підозрюваний. Такий вид впізнання дозволяється проводити на місці події. Після проведення впізнання слід негайно з'ясувати і зафіксувати ступінь впевненості впізнаючого у своїх показаннях.

Крім вищевказаних правил, інструкція вказує на дотримання вимог, що сприяють дотриманню права підозрюваного на захист під час проведення оперативного впізнання “showup". Так, особі, яка впізнає, попередньо необхідно роз' яснити, що особа, яка пред'являється для впізнання, не обов'язково є реальним злочинцем, ним може бути зовсім інша людина. Не допускаються будь-які слова, жести чи інша поведінка співробітників поліції, які мають характер підказки або вказівки на певну особу [12].

Треба зазначити, що в окремих випадках мають місце факти «впізнавання» підозрюваного потерпілим до моменту початку зазначеної процедури, наприклад, в процесі проведення оперативно-розшукових заходів. В таких ситуаціях пред'являти особу для впізнання повторно немає сенсу. Однак факт впізнавання підозрюваного потерпілим може бути відображений в протоколі допиту. Зазвичай цей протокол приймається судами як допустимий доказ.

На переконання науковців, зазначені дії та їх оформлення цілком припустимі, оскільки потерпілий або очевидець, який упізнав підозрюваного, робить це стихійно. Попередньої психологічної підготовки до майбутньої ідентифікації особи не відбувається. Ці обставини, безсумнівно, сприяють відносно спокійному душевному стану особи, яка здійснює впізнання. Крім того, такі факти часто відбуваються в процесі проведення оперативно-розшукових заходів, наприклад, спільного з потерпілим або свідком патрулювання теритоpiï, прилеглої до місця вчинення кримінального правопорушення. Якщо при цьому здійснюється впізнавання підозрюваного, то крім нього там можуть знаходитися й інші особи, тобто фактично впізнаючий бачить не одного підозрюваного, а кількох осіб [4, с. 102-103].

Прикладом порушення процесуальної форми, яке потягло за собою визнання доказів недопустимими, є постанова Касаційного кримінального суду у складі Верховного Суду від 18 грудня 2019 року (справа № 761/2021/16-к, провадження № 51-3904км19), відповідно до якої Вирок Шевченківського районного суду м. Києва від 24 листопада 2017 року та ухвалу Київського апеляційного суду від 07 травня 2019 року щодо ОСОБА_1 за обвинуваченням у вчиненні злочину, передбаченого ч. 1 ст. 186 КК України, залишити без зміни. Суди обох інстанцій обгрунтовано зазначили, що протокол пред'явлення особи для впізнання потерпілою ОСОБА_2 від 18.07.2015 року є недопустимим доказом, оскільки він отриманий з порушення вимог ст. 228 КПК України.

3 показань потерпілої ОСОБА_2 та свідка ОСОБА_3 вбачається, що обвинуваченого перед впізнанням, яке було здійснено у відділенні міліції, пред'явили потерпілій на вулиці. При цьому інші особи для впізнання їй не пред'являлися в цей час. Також потерпіла вказала, що впізнання на досудовому розслідуванні за фотознімками відбулося за її участі вже після того, як працівник міліції попередньо продемонстрував їй на вулиці затриманого ОСОБА_1 як схожого по її описам чоловіка, якого вона пізніше впізнавала в процесі 
слідчої дії. Зазначила, що особи, які пред'являлися їй для впізнання, мали інші ознаки зовнішності за тілобудовою, віком, зростом, були старші від ОСОБА_1. Також під час впізнання були відсутні поняті. Сам же ОСОБА_1 заперечував щодо вчинення грабежу відносно потерпілої ОСОБА_2. Також він зазначав про те, що його повторно представили для впізнання потерпілій серед осіб, які за зовнішністю не були подібні до нього, мали суттєві відмінності.

У сукупності доказів, на яких базувалось обвинувачення, протокол пред'явлення особи для впізнання відігравав вирішальну роль, він був об'єднуючим, закріплюючим елементом, адже протокол огляду місця події від 18.07.2015 року, протокол слідчого експерименту за участю потерпілої від 11.08.2015 року є непрямими доказами, і вони мали значення для доведення вини ОСОБА_1 лише в сукупності із протоколом пред'явлення особи для впізнання. Тому твердження прокурора, що судами не надано належної оцінки вищевказаним доказам, не вбачається обгрунтованим.

Суди належно вказали на те, що зазначені вище докази не можуть бути достатньою підставою для висновку суду про винуватість ОСОБА_1 у вчиненні ним 18 липня 2015 року грабежу щодо потерпілої ОСОБА_2 [13].

Фіксування кримінального провадження передбачене гл. 5 КПК України (ст. ст. 103-109). Ст. 103 КПК передбачає такі форми фіксації процесуальних дій: протокол, носій інформації, на якому за допомогою технічних засобів зафіксовані процесуальні дії, і журнал судового засідання. Під час фіксації фактичних даних слідчі часто допускають порушення вимог закону відносно порядку проведення відповідної процесуальної дії, порядку фіксації процесу та результатів, проте фіксують докази, які прямо вказують на причетність тієї чи іншої особи до вчиненого злочину.

Протокол складається з вступної, описової та заключної частин. У вступній частині повинні міститися відомості про місце, час проведення (час початку і закінчення) та назву слідчої (розшукової) дії; особу, яка проводить пред'явлення для впізнання (посада, звання, прізвище, ім'я, по батькові); прізвища, імена, по батькові, дати народження, місця проживання всіх осіб, які були присутні під час проведення дії (захисник, перекладач, спеціаліст, поняті). В описовій частині протоколу пред'явлення для впізнання мають бути вказані анкетні дані особи, яка упізнається, iї зріст, риси обличчя, колір волосся, одяг, процесуальне становище, а також прізвища, імена, по батькові, основні ознаки, вік, зріст, колір волосся, одяг і адреси тих осіб, серед яких вона пред'являється для пізнання. У заключній частині протоколу повинні міститися відомості про спосіб ознайомлення учасників слідчої (розшукової) дії зі змістом протоколу, зауваження і доповнення до письмового протоколу з боку учасників процесуальної дії [5, с. 394-395].

Прикладом порушення процесуальної форми, яке потягло за собою визнання доказів недопустимими, є постанова Касаційного кримінального суду у складі Верховного Суду від 21 липня 2020 року (справа № $331 / 2390 / 17$, провадження № 51-1230км20), відповідно до якої Ухвалу Апеляційного суду Запорізької області від 3 грудня 2019 року стосовно ОСОБА_1 за обвинуваченням у вчиненні злочинів, передбачених ч. 2 ст. 190 , ч. 2,3 ст. 185 КК України, залишити без зміни.

Як убачається 3 матеріалів кримінального провадження, доказами у кримінальному провадженні, окрім іншого, були протоколи пред'явлення особи для впізнання, які належним чином дослідив суд першої інстанції та визнав їх недопустимими, при цьому зазначив, що у протоколах пред'явлення особи для впізнання відсутній опис усіх осіб, які пред'являлись для впізнання за номерами від одного до чотирьох, а також не зазначено про те, хто є тією особою (ПІБ), яку свідок впізнав на відповідних фото (відомості щодо анкетних даних осіб не зазначені), та спосіб, у який було проведена така слідча дія, що призвело до порушення вимог статті 228 КПК.

Тобто суд, проаналізувавши всі надані стороною обвинувачення докази, визнав недопустимими всі протоколи пред'явлення особи для впізнання, а також протокол слідчого експерименту від 30 березня 2017 року за епізодами вчинених ОСОБА_1 крадіжок у період 311 січня по 13 січня $201 \overline{7}$ року, оскільки виправданий у своїх показаннях зазначив, що він лише фотографувався на фоні приміщень, на які вказував слідчий, а понятими були особи без постійного місця проживання. Таких свідків стороною обвинувачення не було представлено суду для підтвердження проведення вказаних слідчих дій відповідно до вимог чинного законодавства.

Тобто рішення про виправдання ОСОБА_1 1 обгрунтованим, а ухвала апеляційного суду відповідає вимогам статті 419 КПК [14].

Проаналізувавши практичні приклади з судової практики, можна зробити висновок, що будьяке порушення процесуальної форми тягне за собою визнання доказів недопустимими. Однак деякі науковці вважають, що несуттєві порушення кримінального процесуального закону не можуть бути підставою для визнання доказів недопустимими. 3 цього випливає необхідність законодавчого визначення, які саме процесуальні порушення є суттєвими. Також є процесуалісти, які дотримуються "доктрини плодів отруєного дерева» (fruit of poisonous tree doctrine), яка діє у кримінальному процесі США і відповідно до якої будь-яке 
порушення поліцейськими конституційних прав громадян, навіть якщо воно має не безпосередній, а лише опосередкований зв'язок із самим процесом виявлення, вилучення та фіксації доказів, тягне втрату останнім юридичної сили. Наприклад, недопустимими є докази, отримані під час обшуку, якщо місце обшуку знайдено по карті, отриманій незаконним шляхом [6, с. 43-49]. На нашу думку, кримінальне судочинство України наразі не готове до такої категоричності у вирішенні питань допустимості доказів.

Висновки. Доказова цінність результатів пред'явлення особи для впізнання безпосередньо залежить від того, наскільки точно було додержано вимоги кримінального процесуального закону щодо необхідних умов для проведення пред'явлення для впізнання і процедури пред'явлення особи для впізнання. На жаль, на практиці нерідкими є випадки перевищеної оцінки результатів впізнання, коли в основу обгрунтування обвинувальних вироків суду покладаються непереконливі й сумнівні протоколи впізнання. Тому здійснення організаційно-тактичних заходів відповідно до вимог проведення пред'явлення особи для впізнання i дотримання наукових рекомендацій слідчим $€$ обов'язковою умовою отримання допустимих доказів у кримінальному провадженні.

\section{Jimepamypa}

1. Бобров В.К., Божьев В.П., Бородин С.В. Уголовный процесс: учеб. для вузов/ под ред. В.П. Божьева. Москва, 1998. 574 с.

2. Золотых В.В. Проверка допустимости доказательств в уголовном процессе. Ростов-на-Дону, 1999. $288 \mathrm{c.}$

3. Іщенко В.І. Принцип допустимості і достатності засобів кримінально-процесуального доказування. Право України. 2003. № 7. С. 80-83.

4. Климчук М.П. Тактика пред'явлення для впізнання особи в Сполучених Штатах Америки. URL: http://elar.naiau.kiev.ua/jspui/bitstream/123456789/ 15982 / 1 / А К Т У А Л Ь Н I \% 20 П И Т А Н Н Я \% 20КРИМІНАЛІСТИКИ_р101-105.pdf.

5. Криміналістика : підручник / [В.В. Пясковський, Ю.М. Чорноус, А.В. Самодін, А.О. Антощук та ін.] ; за заг. ред. В.В. Пясковського. 2-ге вид., перероб. і допов. Київ : Право, 2020. 752 с.

6. Орлов Ю.К. Основы теории доказательств в уголовном процессе : науч.-практ. пособие. Москва, 2001. $144 \mathrm{c}$.

7. Осетрова О.С. Дотримання процесуальної форми як критерій допустимості доказів. Юридичний часопис Національної акаделї внутрішніх справ. 2014. №1. c. 142-154 URL: http://elar.naiau.kiev.ua/ bitstream/123456789/845/2/osetrova.pdf.

8. Самофалов Л.П. Роль процессуальной формы в реализации конституционных прав и свобод советских граждан в их отношении с милицией : автореф. дис. канд. юрид. наук. Киев, 1987. 22 с.

9. Толочко О.М. Гуманізація доказування у кримінальному провадженні. Науковий часопис Націо нальної академії прокуратури України. № 4. 2014. C. 187-196.
10. Чельцов-Бебутов М.А. Курс уголовно-процессуального права. Санкт-Петербург, 1995.867 с.

11. Шульга Н.В. Допустимість відомостей, отриманих за результатами відео конференції. Прикарпатський юридичний вісник. 2017. №5 (20). с. 222-225. URL: http://www.pjv.nuoua.od.ua/v5_2017/54.pdf

12. Guidelines for conducting show ups. Port Washington Police Department, Wisconsin. URL: http:// defensewiki.ibj.org/index.php/Showups,_Lineups, and \% 20Photo Arrays.

13. Постанова Касаційного кримінального суду у складі Верховного Суду від 18 грудня 2019 року у справі № 761/2021/16-к, провадження № 51-3904км19. URL: http://reyestr.court.gov.ua/Review/86505832.

14. Постанова Касаційного кримінального суду у складі Верховного Суду від 21 липня 2020 року у справі № 331/2390/17, провадження № 51-1230км20. URL: http://reyestr.court.gov.ua/Review/90563134.

15. Постанова Касаційного кримінального суду у складі Верховного суду, від 11 лютого 2020 року у справі №761/33311/15-к, провадження № 51-487км18. URL: http://reyestr.court.gov.ua/Review/87672462.

\section{Анотація}

Гриненко К. В. Допустимість доказів, отриманих під час пред'явлення особи для впізнання. - Стаття.

Наукова стаття присвячена висвітленню деяких аспектів процедури проведення слідчої (розшукової) дії, а саме пред'явлення особи для впізнання. Метою статті $\epsilon$ аналіз вивчення одного з важливих критеріїв допустимості доказів у кримінальному судочинстві - процесуальної форми. Досліджено різні погляди науковців щодо понять допустимості доказів та процесуальної форми, адже сьогодні термін «процесуальна форма» не визначений жодним нормативним документом.

Розглянуто організаційні й тактичні особливості пред'явлення особи для впізнання та проаналізовано процедуру проведення цієї слідчої (розшукової) дії у зарубіжних країнах, зокрема у Сполучених Штатах Америки. У статті наведено приклади судових рішень, у яких докази визнано недопустимими з огляду на порушення процесуальної форми. Зокрема, акцентується увага на проблематиці дотримання належної процедури одержання доказів та фіксуванні результатів дії. Зазначено причини порушення умов допустимості доказів під час досудового розслідування та можливості їх усунення.

$\mathrm{y}$ статті наголошено, що відповідно до чинного законодавства та судової практики будь-яке недотримання процесуальної форми є підставою до визнання доказів недопустимими, що призводить до недоведеності вини підозрюваної особи. Проаналізовано думки деяких науковців, які вважають, що несуттєві порушення кримінального процесуального закону можуть вважатися допустимими у разі законодавчого визначення, які саме процесуальні порушення є суттєвими.

Зроблено висновок, що сторона обвинувачення під час збирання та фіксації доказів має докласти максимальних зусиль для дотримання всіх вимог проведення процесуальної дії відповідно до кримінального процесуального закону, адже це є обов'язковою умовою отримання допустимих доказів у кримінальному провадженні. Для того щоб докази були достатньою підставою для висновку суду про винуватість особи, процедура та протокол пред'явлення для впізнання мають бути належними.

Ключові слова: пред'явлення особи для впізнання, допустимість доказів, недопустимий доказ, процесуальна форма, досудове розслідування. 


\section{Summary}

Hrynenko $K . V$. Admissibility of evidence obtained during the presentation a person for identification. Article.

The scientific article is devoted illumination of some aspects of the procedure of conducting an investigative (search) action, namely the presentation a person for identification. The purpose of the article is to analyze the study of one of the important criteria for the admissibility of evidence in criminal proceedings - the procedural form. Different points of view of scientists on the concepts of admissibility of evidence and procedural form have been studied, because today the term "procedural form" is not defined by any normative document.

The organizational and tactical especially of producing a person for identification are considered and the procedure of conducting this investigative (search) action in foreign countries, in particular in the United States of America, is analyzed. The article provides examples of court decisions in which evidence was declared inadmissible due to violation of procedural form. In particular, attention is focused on the issue of compliance with the proper procedure for obtaining evidence and recording the results of action. The reasons for violation of the conditions of admissibility of evidence during the pre-trial investigation and the possibility of their elimination are indicated.

The article emphasizes that in accordance with the current legislation and judicial practice, any non-compliance with the procedural form is grounds for declaring the evidence inadmissible, which leads to the lack of proof of guilt of the suspect. The opinions of some scholars are analyzed, who believe that insignificant violations of the criminal procedural law can be considered admissible in the case of legislative determination of which procedural violations are significant.

It is concluded that the prosecution during the collection and recording of evidence should make every effort to comply with all requirements of the procedural action in accordance with the criminal procedure law, as this is a prerequisite for obtaining admissible evidence in criminal proceedings. In order for the evidence to be a sufficient basis for a court's finding of guilt, the identification procedure and protocol must be appropriate.

Key words: presentation a person for identification, admissibility of evidence, inadmissible evidence, procedural form, pre-trial investigation. 